\title{
Sustainable development of urban slum areas in northwestern Spain
}

This is a post-print version of the author. The final text archive is available on Emerald Insight at: http://dx.doi.org/10.1108/MEQ-06-2014-0095

\author{
Carmen Gago-Cortés \\ Economic Analysis and Business Administration, University of A Coruna, \\ A Coruña, Spain, and \\ Isabel Novo-Corti \\ Economic Development and Social Sustainability Research Group, \\ University Institute of Maritime Studies, Spain and \\ Economic Analysis and Business Administration, \\ University of A Coruna, A Coruña, Spain
}

\begin{abstract}
Purpose.- The persistence of shanty towns in cities is a major public issue due to the situation of poverty and abandonment of its inhabitants. Despite public authorities are concerned about this serious issue, they often fail to address suitably the problem due to their short term goals. In this paper, public policies and green economy projects to improve the quality of life of people living in shanty towns are assessed in northwest Spain from the point of view of sustainable development and the interaction between social, economic and environmental areas.
\end{abstract}

Design/methodology/approach.- A systemic causal diagram is proposed for the empirical analysis. It has been contrasted through the study of the various actions undertaken in some shanty towns in Spain. Semi-structured interviews were conducted to complement this analysis.

Findings.- As a result, the study shows that the actions should not only be limited to providing access to adequate housing, but should also require more extensive crosscutting projects. In this, green economy policies are shown as a good choice for improving the quality of life and development of the population.

Originality/value.- The study highlights the potential of green economic policies to mitigate environmental problems in slum areas and to support the social and economic development of its inhabitants. This paper provides some lines of action to improve the efficiency of public policies implemented in these cases. Thus, benefits in multiple areas such as social, environmental and urban could be generated.

Keywords. Public policy, green economy, urban, slum, municipal governance, social inclusion.

Article classification. Research paper 


\section{Introduction}

In recent times, we have been experiencing a worldwide phenomenon that has been called the "urbanization of poverty". The foci of poverty are shifting to cities. This is a situation which is aggravated by the serious economic crisis. One of the most obvious signs of this process is the formation of shanty towns, whose inhabitants are surviving amidst poverty and neglect (United Nations, 2006). The institutional concern about this serious problem is captured in Europe 2020, which is aimed at the EU countries achieving a set of challenges on a collective basis, in order to get out of the crisis through a clever, sustainable and inclusive growth. The European Platform against poverty initiative is included within this strategy, whose objective is the recognition of fundamental rights for people experiencing poverty and social exclusion, promoting their active participation in society (European Commission, 2010).

The inhabitants of shanty towns are one of the social groups with a higher need for aid programs, as they are in a situation of multiple deprivations (Clarke, 2006), in which social exclusion combines with various problems in fields such as employment, education or health, and the spatial and relational segregation. There is a causal vicious circle: bad housing conditions hamper access to services and facilities. This contributes to the socio-economic deprivation, and those disadvantages hinder the access to an adequate house (Begum and Moinuddin, 2010).

However, in many cases, the authorities do not consider this causal diagram when designing and implementing housing allocation procedures for residents of shanty towns. Policy makers are driven by urban planning, and they decide to carry out actions even at the price of its social and economic sustainability in the medium and long term. Such policies could fail for not taking into account the need to incorporate services and encourage urban systems that improve the welfare of both the affected people and the society. These actions demonstrate the importance of good governance for sustainable urban development (Rana, 2011).

In the case of Spain, it should be added that $90 \%$ of people living in the shanty towns are members of the gypsy ethnic group (Open Society Institute, 2002). Phillips (2010) examines the persistence of problems of discrimination and social exclusion of minority groups in European Union-15 countries, particularly affecting the Roma people. For instance, according to the Spanish Sociological Research Centre, $40.2 \%$ of people surveyed, at a national level, said that they feel very or fairly upset about having Roma neighbours (Centro de Investigaciones Sociológicas, 2005). Phillips identifies three main reasons for government intervention in the shanty towns: the high levels of poverty and exclusion, the lack of interest in integration of these minority groups and the social disorder problems. 
One of the most utilised public policies for the eradication of slum areas in Spain are those focusing on the relocation of people living in shanties in new normalized housing, for subsequent demolition of the shanty towns. However, it is not clear that housing access policies and de-segregation by themselves will reduce the social exclusion suffered by the inhabitants of these shanty towns (Somerville, 1998; Bolt et al., 2010).

In northwest Spain, there are some cases where these urban development policies were implemented according green economy postulates. That is to say, taking into account the improvement of the urban landscape and incorporation of green areas, positive effects may be achieved, as is the case of the shanty town so called O Portiño. In this case an urban space was fully renovated with a proper access, and recreation areas. This action automatically revalued land and houses in the area. And, as a consequence, this initially remote area became a meeting point for building new social relationships.

Beside these positive aspects, there is the ecological and environmental impact of the regeneration of these areas. Very often, shanty towns do not have proper waste management and lack adequate sanitation, making these spaces unhealthy areas. In addition, these shanty towns are often located close to uncontrolled landfills. As we show in this study, an adequate municipal plan for the management and waste treatment could transform these areas, providing a healthy environment. Therefore, the provision of these services is a big challenge faced by the local authorities (McGranahan et al., 2005).

For these reasons, it becomes necessary to discuss what sort of measures ultimately lead to a sustainable improvement of the living conditions of inhabitants of shanty towns in northwestern Spain. The purpose of this paper is to assess the public policies and green economy projects implemented in order to achieve a sustainable development in social, economic and environmental areas. For this aim, a systemic causal diagram is proposed, and semi-structured interviews were conducted whith the main actors involved in the design and implementation of this kind of policies.

The paper is structured as follows: In Section 2, the background on slum clearance policies is analysed in terms of social inclusion of its inhabitants. The research methods used to analyze these policies are set out in Section 3. Section 4 describes the results of the analysis of public programs of slum clearance conducted in Spain, distinguishing those policies that get the best social inclusion and achievement of well-being. Finally, the conclusion section highlights the need for cross-cutting projects that combine the social and economic sustainability with the care for their surroundings and the environment, in line with the United Nations recommendations (United Nations Human Settlements Programme, 2012). 


\section{Background}

Social inclusion is identified with those processes in which the access barriers are eliminated through a two-pronged process, in accordance with the Common Agenda for Integration (Commission of the European Communities, 2005). On the part of the minority group, the acceptance of certain basic social norms is necessary, which are essential for proper cohabitation and for establishing relationships with the majority of society. Needless to say, that adaptation for coexistence is perfectly compatible with keeping their own ethnicity and culture rules (United Nations Human Settlements Programme, 2012). Meanwhile on the part of the majority group, it is necessary to create an atmosphere of openness to social diversity, by preventing attitudes of avoidance or harassment of the minority groups.

The presence of substandard housing is a problem for those who inhabit them and also for those who are living in surrounding areas, and, even for those who are conscious of their existence. As Sen (1992) points out, the hardships suffered by people with low income represent a "discomfort" and cause "problems for those who are not poor". Therefore, the lack of decent housing is inconsistent with the well-being desired by today's societies, which require the assumption and compliance with certain standards commonly established for living together (Richardson, 2006). From this point of view, improving the living conditions of people residing in slums and substandard housing is also an improvement in social welfare. This positive externality justifies the intervention of public agencies in this field with housing and social policies aimed at fostering inclusion. The type of policies that individual governments decide to implement will be one of the determining factors in explaining the social and spatial inequality in cities (Jiménez, 2008).

Access to housing is an essential element in today's society. Residence in a standard house, in an integrated habitat, opens the door to resources and services, while favoring coexistence and social cohesion. On many occasions, though people have access to housing, this property does not meet the minimum conditions of habitability, and this is also a factor for exclusion (Subirats et al., 2004). Therefore, access, location and living conditions are key points to keep in mind when analyzing the relationship between housing and social exclusion. A person who resides in a remote building with no access to running water or electricity, which does not fulfill the structural requirements to qualify as decent housing, thus, is a person who will have fewer opportunities for access to employment, education and healthcare. Therefore, adequate public housing policy performance becomes critical to achieving sustainable and socially equitable cities, in line with the objectives of the Europe 2020 Strategy.

In the European Union, according to Eurostat for the year 2012, over 25 million people suffer from severe housing deprivation. This represents $5 \%$ of the total population. Romania and Hungary are the EU countries suffering from this problem to a greater 
extent ( $22.8 \%$ and $17.2 \%$ of the overall population, respectively), while Spain is below the average range with $1.3 \%$ of the population affected, although still quite a distance from the country with the lowest percentage, which is Belgium, with $0.6 \%$ of the total population (Eurostat, 2014).

Faced with this problem, governments face the great challenge of designing and implementing sustainable policies for improving access to housing that contribute to the reduction of social exclusion of minority groups in a sustainable environment. In this way, the urban green actions are a key toehold for policy makers. Social and environmental goals can be achieved at the same time, through the design of more effective public policies that promote co-benefits in these areas. This is possible thanks to the close relationship between urban form and social sustainability (Karuppannan and Sivan, 2011). The environmental development of slum areas and their transformation into new urban green spaces, facilitate the social interaction of their inhabitants. Previous research in northwest Spain highlights the importance of this interaction to promote positive attitudes of acceptance and social inclusion in the framework of public policies of relocation and slum clearance (Gago-Cortés and NovoCorti, 2015).

Furthermore, the implementation of green economy projects in the slums could also help to achieve the goals both of social and environmental sustainability. According to the United Nations Environment Programme (2012), the employment generated through these projects has a direct social impact, while there are other cross-sectoral impacts, like the improvement of health and access to clean energy.

\section{Research methods}

\subsection{Causal model of access to housing policies in urban slums}

The system dynamics methodology is employed for the analysis of policies for access to housing for people who live in shanty towns. This methodology takes into account the interdependence of the various factors involved in a problem. This interdependence triggers the formation of feedback loops. Furthermore, this methodology allows to incorporate time lags between causes as well as the effects of a particular policy and also the nonlinear relationships. Making the most of these aspects, a causal diagram has been drawn by using the Vensim DSS software, version $6.0 \mathrm{~b}$. The systems archetype of counterproductive solutions, or of quick fixes that fail (Senge, 1993), has been taken as the basis for this processing. This archetype relies on that every decision has consequences in the short and long term. These consequences are often opposed. If a fast solution is applied, the initial problem is alleviated, but the unintended consequences of this solution will make the problem worse in the long run. 
Figure 1 shows the causal diagram developed to analyze policies for access to housing by the people living in shanty towns. The dotted arrows indicate situations in which the municipal government decided to implement short-term policies for the provision of new housing to ensure implementation of rehousing, thus rapid eradication of shanty towns will be achieved. In this situation, the more shanties there are in the urban slum, the greater provision of housing will be needed, resulting in more relocations. In turn, this increase in relocations will decrease the number of shanties in the slum (balancing loop B2). The grey arrows show how these short-term policies may become counterproductive in the medium term, if the necessary social and economic adaptation does not occur. The result is that families can only stay in the new home for a very limited time, and once forced to abandon their new homes, the problem of slums will resurface. More specifically, the increase of policies based solely on the provision of housing, will hinder social adaptation of families in the new environment decreasing the residence time in new homes. This shorter residence time or abandonment of housing will cause an increase of shanties in slums, closing the reinforcing loop R1. The same happens in R2 loop when families in the new houses provided cannot afford the expenses, reducing in this way the length of stay. And finally, the black arrows include those actions in housing that will be sustainable over time. Sustainable housing programs should include cross-cutting policies that contemplate environmental development, social inclusion, and an economic development that allows the financial sustainability of the public program. The higher the number of shanties in slums, the greater the number of such programs which should be applied with the purpose of achieving a steady decline in the number of shanties that permits the disappearance of urban slums (balancing loop B1). 


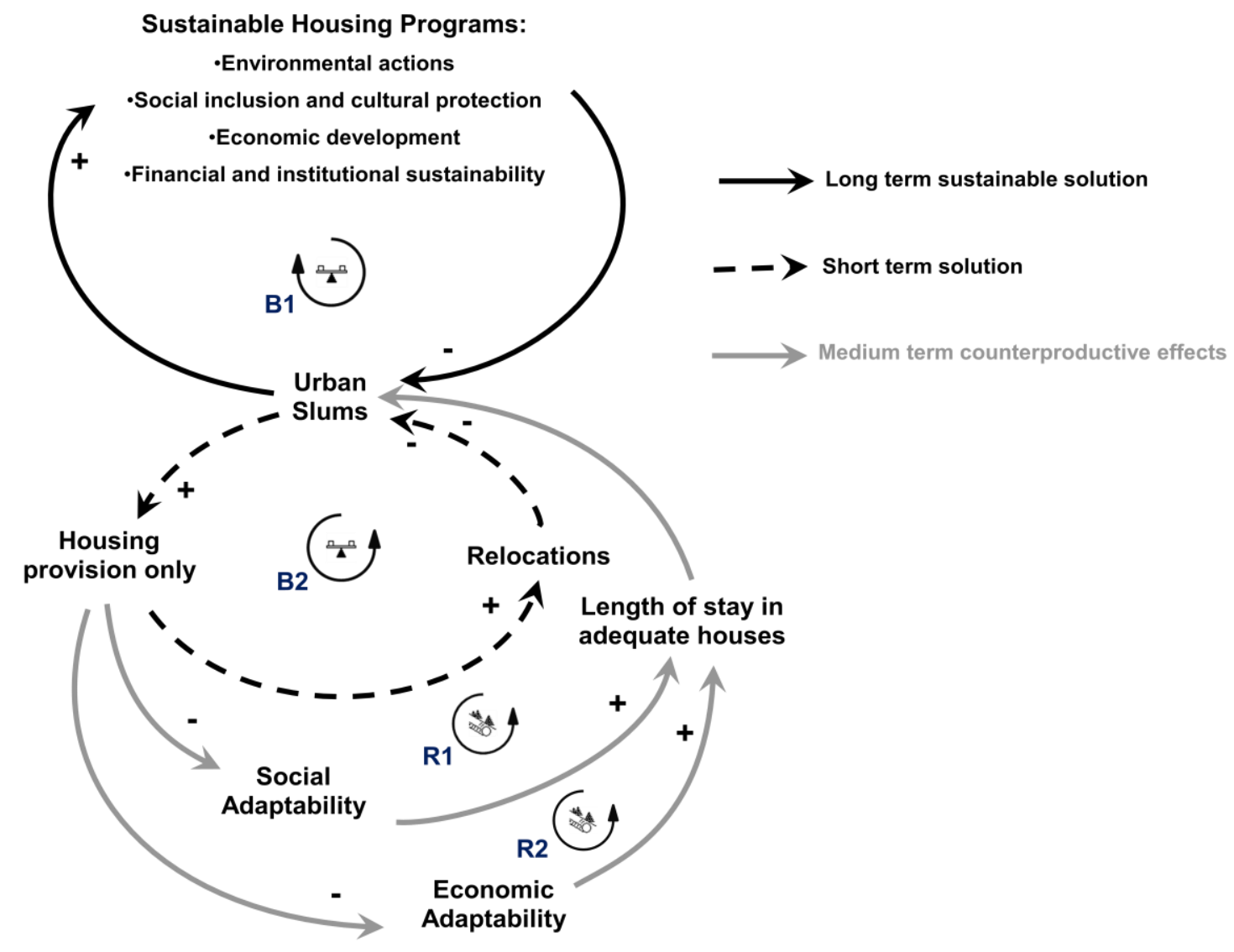

Figure 1: Causal model with the effects of access to housing policies in urban slums.

\subsection{Data collection}

To test our causal diagram, we conduct an in-deep analysis of some relocation policies conducted in Spain, over the past years, to improve the welfare and quality of life of people living in shanty towns. Also, we thoroughly analyze two actions carried out recently in northwestern Spain, focusing on the strengths and weaknesses of each of these particular actions, contrasting them with the academic theoretical body.

Finally, seven in-depth interviews were carried out. Participants were chosen among the main actors involved in the design and implementation of slum clearance policies in northwest Spain (see Table I). Respondents provided interviews in a voluntary and anonymous way. Experts 1 to 3 belong to one of the cities in northwestern Spain most affected by this problem, with experts 2 and 3 being representatives of two of the neighborhoods where people have been relocated from slums. Experts 4 to 7 belong to the three main NGOs who are actively fighting this problem in northwest Spain: Association of Gypsy Promotion and Integration ${ }^{1}$, Architects Without Borders ${ }^{2}$ and Fundación Secretariado Gitano ${ }^{3}$.

\footnotetext{
${ }^{1}$ Association of Gypsy Promotion and Integration: This association manages programs promoting education, a family approach to school, employment, housing rehabilitation and cultural promotion of the Roma people in northwest Spain.
} 
Table I. Data of the interviewees

\begin{tabular}{|c|c|c|}
\hline Identification & Position & Institution \\
\hline Expert 1 & $\begin{array}{l}\text { Councillor for Social Services (2007- } \\
\text { 2011) }\end{array}$ & $\begin{array}{l}\text { Affected city council (with more than } 200.000 \\
\text { inhabitants) }\end{array}$ \\
\hline Expert 2 & President & Affected community of owners \\
\hline Expert 3 & President & Affected neighborhood association \\
\hline Expert 4 & President & Association of Gypsy Promotion and Integration (NGO) \\
\hline Expert 5 & Social worker & Architects Without Borders (NGO) \\
\hline Expert 6 & Social worker & Fundación Secretariado Gitano (NGO) \\
\hline Expert 7 & Coordinator & Fundación Secretariado Gitano (NGO) \\
\hline
\end{tabular}

Source: Own elaboration

Interviews were conducted during July, August and September 2014, with a length ranging from 15 to 120 minutes, and an average length of 25 minutes. The comments were collected by recording voice and notes. A semi-structured interview format was carried out, including the general questions of Table II.

Table II. General Questions of Semi-Structured Interviews

1. Which are the main issues that you think influence the political decision to intervene in the shanty towns?

2. In this public intervention, what are the main actions that should be carried to improve the situation of the inhabitants of shanty towns? Which actions should not be avoided?

3. If a family living in a shanty town is relocated, what issues should be taken into account for this family to remain in the standard house?

Source: Own elaboration

Once collected, the information was analyzed by classifying the opinions according to its correspondence with the model.

\section{Results: public policy analysis for eradication of shanty towns}

\subsection{Counterproductive effects of the policies}

A large number of policies implemented in Spain for slum clearance are reflected in the grey line pattern in our model (Figure 1), the shanty towns are usually far from the urban core and lack the minimum services and facilities such as water or electricity. If these population centres are not in conflict and are located far from the city, there is not usually a significant public intervention. This lack of intervention is usually made clear when the problem becomes visible due to increasing urbanization, caused by the expansion of the city into areas occupied by these settlements (Echazarra, 2009). Three of our interviewees agree with this author. They show how urban planning is a

\footnotetext{
${ }^{2}$ Architects Without Borders: They work mainly on projects of developing education and awareness in order to facilitate the achievement of the Millennium Development Goals and the search for decent social housing.

${ }^{3}$ Fundación Secretariado Gitano: This foundation has projects and services to provide equal opportunities for the Roma community, particularly in the areas of employment, education and housing. In northwestern Spain they have signed agreements with various municipalities to implement plans to eradicate slums.
} 
key issue for political decision of intervention (see Table III). Other factors that the participants indicate as relevant, are the economic ones and the political goal of getting votes, that propels the public authorities to implement environmental actions that beautify the area.

Table III. Evaluation from Interviewees of the Factors that Influence the Political Decision to Intervene in the Shanty Towns

\begin{tabular}{ll}
\hline Factors & Answers \\
\hline $\begin{array}{l}\text { Obtaining votes } \\
\text { environmental actions }\end{array}$ & $\begin{array}{l}\text { "The vote, that's the final goal. I think the vote is the goal of all politicians. } \\
\text { I don't say that they don't care, but the vote is fundamental. Then the } \\
\text { changing area is very attractive, remove a shanty town and put up a } \\
\text { building, and plant some plants and some grass, and everyone is happy } \\
\text { and the world is ideal and that's worth a lot of votes and sells well. Then } \\
\text { this is that they do, and the dispersion policies of these people are not } \\
\text { good because there are complaints, mess and because of this it is not } \\
\text { interesting and that's kinda what happens" (Expert 2) }\end{array}$ \\
\hline "Fundamentally and based on the experience I've had and observed, \\
urban planning or urban policies, that is to say... and also I think it's not \\
bad, they should be different possibly, but those are not bad, in the sense \\
that they produce pressure to stay on the road to doing it" (Expert 1) \\
"Factors mainly urban planning, some urban intervention that it is \\
necessary to do in the city" (Expert 6) \\
"This question is complicated, I think that important decisions are \\
determined by urban policy or economic factors. I am not aware that the \\
disappearance of a shanty town is exclusively driven by the search for \\
social improvement for its inhabitants. It's very hard to say this, but there \\
are facts that prove it" (Expert 7)
\end{tabular}

Source: Own elaboration

The history of interventions in shanty towns in Spain shows the failure of short term policies. Slum areas in this country are mostly inhabited by Roma people. Until the late 1950s, the members of this minority were living scattered in the outskirts of the Spanish cities, in small kin groups. Empty public undevelopable spaces were the ones chosen for occupation. But during the period 1958-1978, an important process of concentration of Roma population occurs. The cities experience a strong expansion process, and the land occupied by this minority are reclassified for construction purposes. The inhabitants of shanties are expelled and transferred to further away from the city. There, these kin groups met other families who had arrived there by the same procedure and then they start forming new big slums (San Román, 1997).

To combat the shanty towns in Spain, one of the most used public policies is the relocation of people. This procedure consists of providing new normalized housing for each of the family units, by providing economic public support so they can bear the cost. As the family relocations are performed, the demolition of shanties is undertaken. Much of the Roma population living in slums or shanties has accessed a 
normalized housing via such a relocation system. But such policies have brought all sorts of problems, which has led to the term "relocation" itself to start to have a negative connotation.

On numerous occasions, the standardized houses used to perform the relocations are located in other disadvantaged areas of the city, a phenomenon that is termed as "horizontal displacements" (Bolt et al., 2009). This is mainly due to affordability of housing in these areas, and a lower level of rejection by neighbours regarding moving the relocations towards these areas. As a result, these families will continue to suffer in their new homes the same problems of poverty and exclusion. Although they soon adapt to their new social network, it continues to be characterized by the absence of opportunities for socio-economic development (Echazarra, 2010).

Other problems presented by this kind of action are those arising from involuntary displacements. It is essential that the families that are coming into a public process of rehousing should take part in the decision making and that such a choice be taken jointly. Collaboration and consensus must be maintained throughout the entire process (Subirats et al., 2012). Without positive attitudes, facing the slightest conflict in the new relocation, the way back to the protection of the shanty town appears as a very probable scenario.Thus, the economic effort of government would have been for nothing.

Also the attitude of public authorities is crucial. When the only goal is simply a "clean" slum area of the city, due to the bad image they produce, then institutions will probably apply inadequate public policies. So, instead of solving the housing problems of slum dwellers, an increased social exclusion could arise. These actions resolve the symptoms of the problem in the short term, but in the medium and long term, the problem could get worse or even become chronic, while there is a persistence in implementing the same policy (Leal Maldonado, 2002).

\subsection{Sustainable housing programs}

As the balancing loop B1 of the model shows, the actions carried out to improve the quality of life and welfare of the population in shanty towns should have sustainability as a goal to prevent chronicity of the problem. Within these actions it is necessary to take into account that the policies for urban and social development must be planned so as to maximize environmental quality (Anguelovski and Martinez Alier, 2014). For this purpose so-called green economy policies are applied. This is a concept that is used to identify the actions related to economic growth and productive systems that try to minimize the environmental impact and resource consumption to achieve higher social welfare (Edui, 2010). These policies seek to support the neediest sectors of the population by promoting the use of renewable energy, providing more jobs, and by combating the degradation of natural resources such as forests and coasts, which are 
among the main sources of livelihood for those with fewer resources (Zeb et al., 2014). Therefore it is a concept that combines two of the main pillars of the actions for the eradication of shanty towns: social inclusion and environmental and ecological preservation (United Nations Environment Programme, 2011).

Some examples of action based green economy policies to apply in shanty towns, that were undertaken in the city of A Coruña, northwestern Spain, are analyzed in this work, as well as the way in which these projects have been carried out and the results obtained so far. The main objective of these actions is to increase the quality of life of slum dwellers and encourage their development in their own environment. These policies have been implemented before the conclusion of the relocation process, which at the point of publication, is still being carried out.

\subsubsection{The community of $O$ Portiño and landscape regeneration}

In 1963, the local government of A Coruña, Spain, decided to eliminate from the centre of the city those areas of extreme poverty. The policy initially applied, to perform this urban reshaping, was the construction of forty-four residences in O Portiño (Blanco and Lorenzo, 2003). This neighborhood is located just outside of the city, opposite the municipal garbage dump. However these dwellings did not comply with the minimum conditions of habitability, as they had no access to essential services such as running water or electricity. This slum is an example of how Roma people concentrations come about through public actions. The inhabitants came from various shanty towns existing at that time in the city (Figure 2). Due to population growth of families relocated, the new formed households were forced to build wooden shacks in the same area. With the support of various charitable organizations, the area was little by little provided with basic services. 


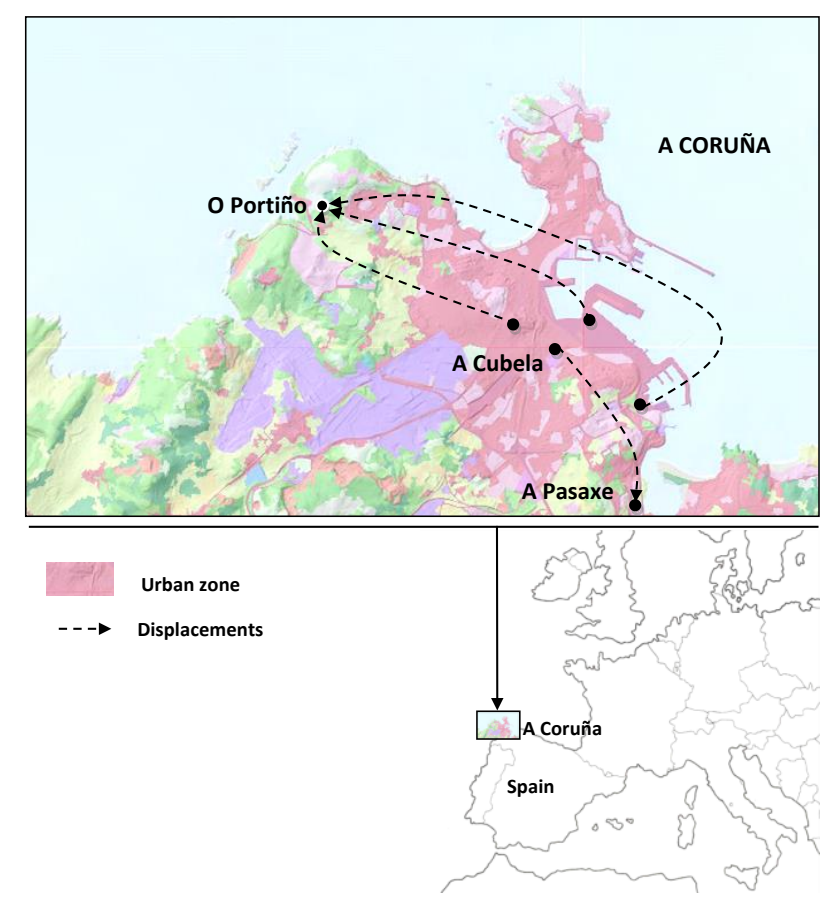

Figure 2: Displacements of shanty towns to the outskirts of the city of A Coruña, Spain. Compiled from data map occupancy of the National Geographic Institute of Spain.

There was no relevant public intervention until the ecological disaster of 1996. In this year, the main landfill of the A Coruña town collapsed. Overuse caused the displacement of 200,000 tons of garbage to the shanty town, and about 300 people had to be evacuated (Blanco and Lorenzo, 2003). The garbage was stretched to the sea and the air of the city became unbreathable. As a result of this incident, the local authorities looked for solutions to regenerate the area and establish an ecological waste treatment system. To achieve this goal, an agreement with several environmental organizations, including Greenpeace, was signed. This project began with the sealing of the old landfill, a project that forces the relocation of over one million cubic meters of garbage (Council of A Coruña, 2000).

The sealing of the landfill has been possible due to the construction of a new plant for the recovery of urban solid waste in the city, which opened in 2002. The rubbish dump was finally closed in 2000; it was waterproofed with layers of bentonite and geotextile, sprawled over 60,000 square meters. In addition, the city has implemented a plan of selective garbage collection.

However, sealing was only part of the project, which encompassed the construction of a wide recreation area, outdoor recreation and enjoyment of nature that includes major reforestation, parks, public facilities, a large botanical garden and a boardwalk, plus the necessary access and parking, with a surface area of about 57 hectares. The project was carried out with the financial resources of the municipality, with aid from 
the European Union and the central administration. The actions taken have allowed the area to provide a great scenic and environmental value. Ecological criteria for conservation, protection and improvement, landscape and environmental values of the fauna, flora, natural balance, etc. were taken into account. The total estimated budget for the entire project was 66 million euros. The new large park was inaugurated on June 5, 2001, coinciding with World Environment Day.

In addition, the biogas resulting from the seal was used to produce energy through a process of cogeneration (for simultaneously getting power and useful thermal energy, such as steam or hot water), which began operating in May 2003. The factory can extract useful energy from the waste. Inside the building there are four engines of 625 $\mathrm{kW}$ each, which, turning, transform the fluid into electricity, which then flows into the network of medium voltage, owned by the Spanish electric company (Union FenosaGas Natural). The council has conducted an economic study to estimate the performance of the new factory. The estimate is that during the twelve years since its opening, revenues of EUR 10.2 million were generated from the sale of electricity.

In 2003, a project was designed to construct 3,200 houses in O Portiño area, which would mean the disappearance of marginal settlement. However this urban project of 494,000 square meters remains on hold because of the economic crisis even it though was approved in 2008 (Council of A Coruña, 2008). The construction of housing and 250,000 square meters of green areas is scheduled. This is a rather large housing complex. Before its standstill, when economic circumstances were radically different, the entry of construction machinery seemed imminent in one of the few spaces that remain to be urbanized in the municipality of A Coruña. Local government showed the dwellers of the core of the slum areas its intention to relocate them in the new urbanization, in social housing with reduced price, for which the neighbours of the zone gave the land. The forecasts were that $20 \%$ of houses would have a reduced official price according the regulation of regional government, but the new regulations could force to qualify $40 \%$ of the flats in this urbanization on the coast as officially protected (Council of A Coruña, 2013).

\section{Benefits}

Following the collapse of the dump, the Association of Residents "O Campanario" was created, with 70 families, with the support of various organizations and, nowadays, it is consolidated and the people are defining themselves as a neighbourhood, living day to day without major cohabitation problems inside or outside the settlement (Blanco and Lorenzo, 2003).

The total rehabilitation of the environment has been a major revaluation of the area, which has become an important tourist attraction of the city, leaving behind its past as 
a marginal and excluded area. The new access and services that have been provided in the area, have contributed to a better quality of life for its inhabitants.

It becomes clear, therefore, the importance of taking into account the environmental quality in the design of community development projects. Environmental projects as listed above, contribute to the historic and cultural preservation, the repair of fragmented communities and community cohesion (Anguelovski and Martinez Alier, 2014), favoring the implementation of measures for social inclusion.

\section{Challenges}

The way of life of the inhabitants of this town was linked to the waste they collected from the landfill. By closing this landfill, they were left without this livelihood. This led them to redefine their activities and, currently, they are working in the collection and sale of scrap metal, or in shell fishing. Nevertheless it is necessary to accompany this change with normalization projects of these activities and programs of access to new job opportunities.

Although at present the development of the area remains paralyzed as a result of the economic crisis, the Roma people realized that the space they occupy now has much more value. They distrust the promises of local government to give them access to the new dwellings projected. They fear becoming homeless if the houses finally are not for them, when the project of urbanization will be done. Therefore, the access to adequate housing is another major challenge for the future of these people.

\subsubsection{The community of A Pasaxe and self-employment project so called "Mulleres} Colleiteiras"

A Pasaxe is another Roma community, in which public policies have been applied for slum clearance. It is also located on the outskirts of the city of A Coruña, Spain. This shanty town arose in 1980, as a result of the decision of the municipal government to eliminate the existing core marginal population at that time in A Cubela. The key reason to vacate $A$ Cubela was the construction of a shopping center; it was really controversial in the city, due to the reclassification of the land and the strong pressure from various lobbies. The displacement of families as a result of this process gave rise to three new shanty towns in the city, one of which is A Pasaxe (Figure 2). People residing in this shanty town survive in extreme poverty. Families living there are divided into three groups, according to their origin: Portuguese, Roma and non-Roma. These families are living completely isolated from the rest of the city. The council held a first attempt to relocate these families by providing them with financial assistance in exchange for leaving the building in which they were staying, and so the municipality could proceed with demolition. But soon after, most people who received the aid for access to housing had moved into a contiguous solar, to build new shanties and then, 
the so-called "submarine effect" was produced: the shanties that governments seek to "bury" are appearing again within days close to the former shanty. This occurs because this is exactly the place where the families have their social circle, but also have their work (San Román, 1997). Currently, municipal intervention in this town is conducted through an eradication plan which aims to foster personal autonomy of its beneficiaries.

To achieve the goal of economic development, Architects without Borders (an NGO) is conducting a pilot project of self-employment for women belonging to this town (Arquitectos sin Fronteras, 2013). It is called "Mulleres Colleiteiras" and consists of the collection, treatment and reusability of the used cooking oil of vegetable origin (soy, olive and sunflower). The process is straightforward: collection, storage (in approved containers at the recycling centers) while the oil is sold directly to an authorized manager for treatment and reuse. The waste collection service is free, and is done in two different ways: through collectors placed around the city and door-to-door collection. The collectors are orange colored and have instructions for properly depositing the waste in plastic containers to prevent spillage. In cases of home collection, bottles suitable for storage are provided.

A year ago, this project was put into operation (April 2013) and nowadays there are 25 volunteers working on the project. We call them voluntary because the women are at a stage where it is not possible to live from the income earned by the project, although this is the ultimate goal (until now profits are only distributed after completion of the collection). This project includes a training program for participants, allowing them to acquire the necessary skills for business management and sales techniques.

This local project is being developed in the city of A Coruña and neighboring municipalities. Its low energy and management costs makes it a viable option to the management of this urban waste.

The ultimate aim is to create a company made up of these women, in which the complete cycle is performed, until the end, when the waste turns into biofuel. Then, this biofuel can be reused locally (e.g. for heating the swimming pool of the University of a Coruna, and also for facilities for municipalities). In order to achieve this objective, some economic support is needed. This project has been submitted to the Social Work of the Spanish bank La Caixa. It is intended to be eligible for the $€ 25,000$ grant provided by this organization for social entrepreneurship.

It is noteworthy that this project of self-employment is not a goal in itself but a means to achieving full inclusion of these individuals in all spheres of society. It seeks to achieve sustainable development through green economy projects, rather than the project as a final goal (United Nations Environment Programme, 2012). So far the results are very positive. There is a wide acceptance of the project by the neighbors of 
A Coruña and influence area. They are favouring the success of this project by giving their used oil. There is also a great improvement in the involvement of women participating in the process.

\section{Environmental and economic benefits}

In the current situation, due to the absence of a separate waste collection, used cooking oil is usually poured down the sink. This cause problems for wastewater treatment plants and energy loss (Felizardo et al., 2006). Used oil is a resource with a high energy potential, as it can be reused as biofuel, renowned for its high calorific value. It is also cleaner than fossil fuel, which will avoid the emission of large quantities of $\mathrm{CO}_{2}$ into the atmosphere.

It also helps promote citizenship awareness on the efficient management of urban waste. Promoting civic ecology practices and generating the conscience of a "positive dependence" of natural resources in order to preserve them are practices that lead to the formation of "virtuous cycles" that increase trust, collaboration and social cohesion levels (Tidball and Stedman, 2012).

\section{Social Benefits}

The main advantage in the social arena is that the project serves as an important vehicle for social and labor integration of excluded women. It seeks to promote female employment of Roma women as a measure of positive action versus a culture and society that favour male employment, treating women as the main engine of social and domestic structure and the care and sustainability of their children

Community and individualized diagnosis made for cohabitation units and the empowerment jobs, undertaken with the people in slums, reflect the basic and fundamental role assumed by women in the change processes, investing in a better future for their children. Hence, the creation of this alternative for self-employment, motivated by change and improving their living conditions, which promotes pro-active attitudes of social integration rather than passive attitudes of continuity in womens' dependence and exclusion.

This project gives these women a chance to integrate into the labor market in a standardized manner. Thus, they can leave behind the informal collection of scrap metal and cardboard. For them, getting the pink uniforms they use in their work is a way to see life completely differently and a different way to be seen by other people.

\section{Challenges}

Access to adequate housing remains one of the major outstanding challenges in the shanty town of A Pasaxe. The failure of the first municipal intervention gave rise to the interventions of access to housing made in a customized way, ensuring certain 
autonomy of families for bearing the costs inherent in the new housing. Due to the extreme poverty in which they live, this task becomes very difficult. Hence, the importance of the self-employment program being conducted, which draws a more positive horizon for these people.

\subsubsection{Common points of sustainable housing programs}

In both cases analyzed, development programs in shanty towns that combine performances in various fields such as environmental, landscape and green economy were implemented. The results of such comprehensive programs have a very important thing in common: a significant empowerment of the inhabitants of these shanty towns, through green policies, has been achieved. This empowerment is contributing to the success of municipal actions. The acquisition of skills and the creation of training and employment opportunities have been demonstrated to be key points that have served as a lever for development and socio-economic sustainability.

Other common aspects of vital importance were the decisions taken by municipal governments. When municipalities opt for sustainable urban development policies in the long term, the results are likely to be more positive (or less negative) than when quick solutions, with horizontal scroll, have been chosen. Given the poverty the slum dwellers face, initial economic support is essential for the access to adequate housing: safe and located in environments that facilitate social integration. But, at the same time, it is necessary to assure the economic and social viability of the project in the long term, with sustainable measures. Thus, governance becomes a key issue in implementing sustainable urban development measures affecting the economy and the enviroment areas, that in particular benefits the most vulnerable parts of the population (Puppim de Oliveira et al., 2013).

Most of our interviewees highlight how important economic development and access to employment are for the success of these policies (see Table IV). 
Table IV. Evaluation from Interviewees of the Factors that Influence the Length of Stay in Adequate Houses

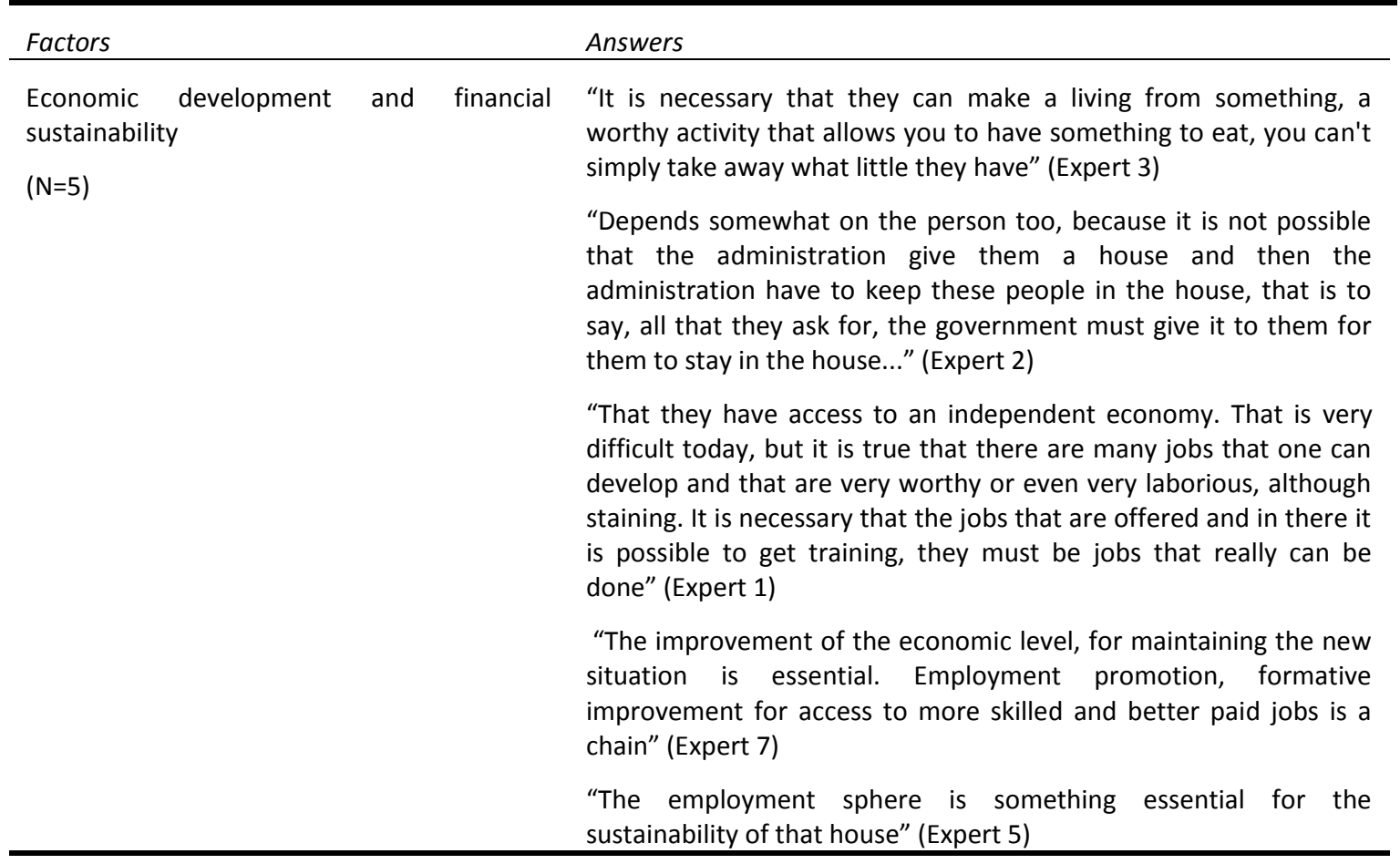

Source: Own elaboration

The participants in our study also give their opinion about the failures and key points of the public policies. Overall they highlighted the need to avoid focusing solely on the provision of a new house and instead promoting social inclusion projects that would facilitate correct adaptation and access to education, health and employment (see Table V). 
Table V. Evaluation from Interviewees of the Main Actions that Should be Carried Out in Slum Clearance Public Programs

\begin{tabular}{ll}
\hline Factors & Answers \\
\hline Social inclusion and cultural protection & "Yes, you know that slum clearance is not only to give a house to a \\
$(\mathrm{N}=6)$ & person, because if a person don't know how to live, it is normal \\
& that this would be a failure" (Expert 4)
\end{tabular}

"First of all, education, because to get them out of a shack, they also have to know where they going, and they have to learn to live with another people, they used to live in another way, but they go to a place where they have to live with people and mingle with them. And I don't say that they have to give up their customs, but they have to respect others" (Expert 2)

"I think it's important to never lose sight of the fact that we are dealing with real people. What is happening is that the social services of the municipality and region and of other associations must provide them with some tools for social skills and there the story ends. For me, all the rest, all that turns into an overprotection or into an absence of duty for the institution responsible for the slum clearance. This is a mistake" (Expert 1)

"I think it's super-important to educate the families since before moving to a new home and especially, in some way give them the benefits of living in a standard house" (Expert 6)

"Another factor that I think is basic is social support in the medium term, these things have not been solved by changing the house, neither have they been solved in the first year living in a new house, because these things imply a number of behavioral changes and alterations in ways of life that don't occur overnight" (Expert 7)

"Architects Without Borders always works based on the formulation of social inclusion plans that take into account all factors that interfere in people's inclusion, that is to say, not only contemplate the habitational sphere of the relocation or of the forced evictions in many cases, but also working in the rest of the social spheres, education issues, health issues, adaptation to house issues and especially the labour area" (Expert 5)

Source: Own elaboration

\section{Conclusions}

This paper aims to assess public policies and green economy projects implemented to improve the situation of people living in shanty towns. Based on a causal model, we have showed that is necessary to include cross-cutting policies in these projects which take into consideration the socio-economic development of the inhabitants and environmental actions which contribute to improving the health and the welfare of society. Evidence was provided with the help of semi-structured interviews with people closely related to relocation issues, combined with case studies as well as theoretical considerations.

The results of the analysis show that some relocation policies to eradicate shanty towns are not designed to ensure relocation success over time. On the contrary, some rehousing processes force inhabitants to leave their shacks, pressing them to change 
their place of residence quickly. Because of this, many of them are living in quite unsuitable dwellings.

Moreover, many of the relocated people do not have the opportunity to maintain their new housing, due to the lack of income when faced with the expenses related to this new situation (economic adaptability), (see Bolt and Van Kempen, 2010). Another issue is the lack of programs to improve people's skills for living in society (social adaptability). Then, a "snowball" effect could appear making the problem worse and perpetuating the need for public intervention (medium term counterproductive effects).

The study shows that the green economy projects analysed in this paper (O Portiño and A Pasaxe shanty towns), which have been implemented both in regenerating environments and self-employment projects, are proper sustainable policies to achieve these two main objectives (Anguelovski and Martinez Alier, 2014; Tidball and Stedman, 2012), which is confirmed by the opinions of the interviewees (long term sustainable solutions).

All in all, we can conclude that those green economy policies are the best practice for achieving a sustainable improvement in the quality of life for people living in shanties.

\section{Acknowledgments}

To the Diputación of A Coruña Spain, for the financial support (15151, August 14, 2014). The authors would like to express their thanks to the participants of the International Conference "Sustainable Energy Use and Management", Targu-Jiu, Romania, May 20, 2014 for their helpful comments and feedback on previous versions of this paper. The paper has also benefited from the comments of Rafael García and the three external reviewers. The authors would also like to sincerely thank all of the interviewees for their participation in the study.

\section{References}

Anguelovski, I. and Martinez Alier, J. (2014), "The 'Environmentalism of the Poor' revisited: Territory and place in disconnected glocal struggles", Ecological Economics, vol. 102, pp. 167-176.

Arquitectos sin Fronteras (2013), "Mulleres Colleiteiras", available at: http://galicia.asfes.org/novas/mulleres-colleiteiras (accessed 14 May 2014).

Begum, H. and Moinuddin, G. (2010), "Spatial dimension of social exclusion. An imperial investigation into the relationship of housing and social exclusion in the slums of Dhaka", Management Research and Practice, vol. 2, no. 3, pp. 314-328. 
Blanco, B. and Lorenzo, P. (2003), "From the city's backyard to a quality residential area: residents, developers and public administrations in the Visma district of $A$ Coruña, Spain", paper presented at Urban Sociology/cities ESA Conference, 24/09/2003, Murcia, Spain, available at: http://www.um.es/ESA/papers/St8_37.pdf (accessed 14 May 2014).

Bolt, G. and Van Kempen, R. (2010), "Dispersal patterns of households who are forced to move: Desegregation by demolition: A case study of Dutch cities", Housing Studies, vol. 25, no. 2, pp. 159-180.

Bolt, G., Van Kempen, R. and Van Weesep, J. (2009), "After Urban Restructuring: Relocations and Segregation in Dutch Cities", Tijdschrift Voor Economische En Sociale Geografie, vol. 100, no. 4, pp. 502-518.

Bolt, G., Ozuekren, A.S. and Phillips, D. (2010), "Linking Integration and Residential Segregation", Journal of Ethnic and Migration Studies, vol. 36, no. 2, pp. 169-186.

Centro de Investigaciones Sociológicas (2005), "Barómetro de noviembre 2005", available at: http://www.cis.es (accessed 06 January 2014).

Clarke, C. (2006), "From slum to ghetto - Social deprivation in Kingston, Jamaica", International Development Planning Review, vol. 28, no. 1, pp. 1-34.

Commission of the European Communities (2005), A Common Agenda for Integration. Framework for the Integration of Third-Country Nationals in the European Union. European Union, Brussels.

Council of A Coruña (2008), "La urbanización de O Portiño contará con 250.000 metros cuadrados de zona verde", available at:

http://www.coruna.es/servlet/ContentServer?pagename=CorunaPortal/Page/Gen ericG-Page-

Generica\&cid=1283931722651\&itemID=1210284955857\&itemType=Suceso (accessed 12 April 2015).

Council of A Coruña (2000), "Plan especial de sellado, cierre y regeneración del actual vertedero de Bens, y de mejora del medio rural en el Monte das Pallas", available at:

http://www.coruna.es/servlet/ContentServer?pagename=CorunaPortal/Page/Gen erico-Page-

Generica\&cid=1283931722651\&itemID=9021022850873230882\&itemType=Conte nido (accessed 12 April 2015).

Council of A Coruña (2013), "Revisión del Plan General de Ordenación Municipal”, available at:

http://www.coruna.es/servlet/Satellite?c=Page\&cid=1213203431354\&pagename= Urbanismo\%2FPage\%2FUrbanismo-Generica (accessed 12 April 2015). 
Echazarra, A. (2010), "Segregación residencial de los extranjeros en el área metropolitana de Madrid. Un análisis cuantitativo", Revista Internacional de Sociología, vol. 68, no. 1, pp. 165-197.

Echazarra, A. (2009), Políticas públicas y segregación residencial de la población extranjera en la Comunidad de Madrid, Fundación Alternativas, Madrid.

EDUI (2010) , "Ecological Development Union International", available at: http://www.green-edui.org/en/jingji.html (accessed 22 October 2014).

European Commission (2010), Europe 2020. A strategy for smart, sustainable and inclusive growth, Communication from the Commission COM (2010) 2020 final, European Union, Brussels.

Eurostat (2014), "Severe housing deprivation rate by age, sex and poverty status", available at: http://epp.eurostat.ec.europa.eu (accessed 23 March 2014).

Felizardo, P., Neiva, M.J., Raposo, I., Mendes, J.F., Berkemeier, R. and Moura, J. (2006), " Production of biodiesel from waste frying oils", Waste Management, vol. 26, pp. 487-494.

Gago-Cortés, C. \& Novo-Corti, I. (2015), "Políticas inclusivas de vivienda a través de la actuación municipal en la erradicación del chabolismo. El realojo del poblado de Culleredo (Galicia, España)", Gestión y Política Pública, vol. XXIV, no. 1, pp. 131167.

Jiménez, F. (2008), "Espacio y sociedad: De la ciudad trizada a la ciudad quebrada", Revista 180, vol. 21, pp. 38-41.

Karuppannan, S. \& Sivam, A. (2011), "Social sustainability and neighbourhood design: an investigation of residents' satisfaction in Delhi", Local Environment: The International Journal of Justice and Sustainability, vol. 16, no. 9, pp. 849-870.

Leal Maldonado, J. (2002), "Segregación social y mercados de vivienda en las grandes ciudades", RES.Revista Española de Sociología, no. 2, pp. 59-75.

McGranahan, G., Marcotullio, P., Bai, X., Balk, D., Braga, T., Douglas, I., Elmqvist, T., Rees, W., Satterthwaite, D., Songsore, J. and Zlotnik, H. (2005), "Urban Systems" in Eades, J. and Ezcurra, E. (Ed.), Ecosystems and Human Well-being. Current State and Trends, 1st edn, IslandPress, Washington, pp. 795-825.

Open Society Institute (2002), Seguimiento de la protección de las minorías en la Unión Europea: La situación de los roma/gitanos en España, Open Society Institute, Budapest. 
Phillips, D. (2010), "Minority Ethnic Segregation, Integration and Citizenship: A European Perspective", Journal of Ethnic and Migration Studies, vol. 36, no. 2, pp. 209-225.

Puppim de Oliveira, J.A., Doll, C.N.H., Balaban, O., Jiang, P., Dreyfus, M., Suwa, A., Moreno-Peñaranda, R. and Dirgahayani, P. (2013), "Green economy and governance in cities: assessing good governance in key urban economic processes", Journal of Cleaner Production, vol. 58, no. 0, pp. 138-152.

Rana, M.M.P. (2011), "Urbanization and sustainability: challenges and strategies for sustainable urban development in Bangladesh", Environment, Development and Sustainability, vol. 13, no. 1, pp. 237-256.

Richardson, J. (2006), "Talking about Gypsies: the notion of discourse as control", Housing Studies, vol. 21, no. 1, pp. 77-96.

San Román, T. (1997), La diferencia inquietante. Viejas y nuevas estrategias culturales de los gitanos, 1st edn, Siglo veintiuno editores, s.a., Madrid.

Sen, A. (1992), "Sobre conceptos y medidas de pobreza", Comercio exterior, vol. 42, no. 4, pp. 310-322.

Senge, P.M. (1993), La quinta disciplina: El arte y la práctica de la organización abierta al aprendizaje, Ediciones Juan Granica, S. A., Barcelona.

Somerville, P. (1998), "Explanations of Social Exclusion: Where Does Housing Fit in?", Housing studies, vol. 13, no. 6, pp. 761-780.

Subirats, J., Riba, C., Giménez, L., Obradors, A., Giménez, M., Queralt, D., Bottos, P. and Rapoport, A. (2004), Pobreza y exclusión social. Un análisis de la realidad española y europea. Fundación" La Caixa", Barcelona.

Subirats, J., Knoepfel, P., Larrue, C. and Varone, R. (2012), Análisis y gestión de políticas públicas, Ariel, Barcelona.

Tidball, K. and Stedman, R. (2012), "Positive dependency and virtuous cycles: From resource dependence to resilience in urban social-ecological systems", Ecological Economics, vol. 86, pp. 292-299.

United Nations (2006), Aplicación coordinada del Programa de Hábitat, E/2006/71, Economic and Social Council, Geneva.

United Nations Environment Programme (2012), Measuring Progress towards an Inclusive Green economy, UNEP, Nairobi.

United Nations Environment Programme (2011), Towards a green economy: pathways to sustainable developmentvand poverty eradication, 1st edn, UNEP, Nairobi. 
United Nations Human Settlements Programme (2012), Going Green: A Handbook of Sustainable Housing Practices, 1st edn, UN-Habitat, Nairobi.

Zeb, R., Salar, L., Awan, U., Zaman, K. and Shahbaz, M. (2014), "Causal links between renewable energy, environmental degradation and economic growth in selected SAARC countries: Progress towards green economy", Renewable Energy, vol. 71, pp. 123-132.

\section{About the authors}

Carmen Gago-Cortés has a Degree in Economics and a Masters in Public Policy and Management from the University of A Coruna (UDC), Spain. She is a Doctorate Student of Official Doctorate Program in Economic and Business Analysis (UDC) since 2011. She received in 2010 the First Prize for Research in the Faculty of Economics of the UDC. In 2013 she obtained a Grant Research granted by the Provincial Council of A Coruña, for the project: Inclusive Housing Policies in the Framework of the Europe 2020 Strategy. She has presented her research at international conferences such as the prestigious International Conference on Applied Business and Economics (ICABE) or theWorkshop on Economic Development and Social Sustainability (EDaSS). At labor level, she has been a Coordinator of the Rental Housing Program of the Xunta de Galicia (Spain) in 2006 and 2007, and of the Emancipation Rent Program of the Government of Spain during 2008-2012.

Isabel Novo-Corti is a Doctor in Economics from the University of A Coruna (UDC), Spain, since 2001. She is a Professor of School of Economic Analysis, and the Head of Department of Economic Analysis and Business Administration, Faculty of Economics of the UDC. She is also an Associate Professor at the National University Center for Distance Education (UNED) of A Coruña, Spain. She emphasizes her research in the field of equality of groups at risk of social exclusion: disability, gender, ethnic minorities and immigrants. She has participated in R\&D projects financed by public funds and is the author of numerous scientific publications of international impact. She serves on the scientific committee of several national and international conferences, for example, National Economy (Association of Economists Galicia, A Coruña, 2005) and ICABE, in 2009 (Kavala , Greece), 2010 (A Coruña) and 2011 (Athens , Greece).

Isabel Novo-Corti is the corresponding author and can be contacted at: isabel.novo.corti@udc.es 